\title{
Synthesis and X-ray crystal structure of a chiral molybdenum porphyrin and its catalytic behaviour toward asymmetric epoxidation of aromatic alkenes
}

\author{
Wei-Sheng Liu ${ }^{\text {a }}$, Rui Zhang ${ }^{\text {a }}$, Jie-Sheng Huang a, Chi-Ming Che ${ }^{\mathrm{a}, *}$, Shie-Ming Peng ${ }^{\mathrm{b}}$ \\ a Department of Chemistry, The University of Hong Kong, Pokfulam Road, Hong Kong, Hong Kong \\ ${ }^{\mathrm{b}}$ Department of Chemistry, National Taiwan University, Taipei, Taiwan, ROC
}

Received 3 April 2001; accepted 15 June 2001

\begin{abstract}
Reaction of $\mathrm{M}(\mathrm{CO})_{6}$ with $\mathrm{H}_{2} \mathrm{P}^{*}$ (5,10,15,20-tetrakis- $\{(1 S, 4 R, 5 R, 8 S)-1,2,3,4,5,6,7,8$-octahydro-1,4:5,8-dimethanoanthracene-9yl porphyrin) followed by treatment with methanol afforded $\left[\mathrm{Mo}^{\mathrm{V}} \mathrm{O}\left(\mathrm{P}^{*}\right)(\mathrm{OMe})\right](\mathbf{1})$ in $\sim 80 \%$ yield. Complex $\mathbf{1}$ was characterised by IR and ESR spectroscopy and X-ray structure determination. This chiral molybdenum porphyrin was found to catalyse the epoxidation of styrene, cis- $\beta$-methylstyrene, and 1,2-dihydronaphthalene with tert-butyl hydroperoxide in up to $29 \%$ ee. C) 2001 Elsevier Science B.V. All rights reserved.
\end{abstract}

Keywords: Catalyst; Epoxidation; Molybdenum; Porphyrin; Structure

\section{Introduction}

Chiral metalloporphyrins constitute an important class of catalysts for asymmetric epoxidation of alkenes. Previous studies on these catalysts are confined to the porphyrin complexes of iron [1], manganese [1], and ruthenium [2], in which cases the epoxidation reactions are widely believed to occur via highly reactive oxometal $(\mathrm{M}=\mathrm{O})$ intermediates $[2,3]$. To expand the scope of metalloporphyrin-catalysed asymmetric alkene epoxidations, we initiated investigations on chiral molybdenum porphyrins, because it has been well documented that molybdenum-catalysed epoxidations with alkyl hydroperoxides usually involve $\left[\mathrm{Mo}\left(\eta^{2}-\mathrm{O}_{2}\right)\right]$ or [Mo-OOR] active intermediates [4].

Molybdenum porphyrins were first prepared by Srivastava and Fleischer in 1970 [5]. Since then numerous molybdenum complexes with porphyrin ligands have been known [6]. However, to our knowledge, all the

\footnotetext{
* Corresponding author. Tel.: + 852-2859-2154; fax: + 852-28571586.

E-mail address: cmche@hku.hk (C.-M. Che).
}

reported complexes bear non-chiral porphyrin macrocycles, which prevents them from functioning as catalysts in asymmetric catalysis. Indeed, while a few alkene epoxidations catalysed by molybdenum porphyrins have been reported [7-9], none of them are enantioselective. We also note that these epoxidation studies are focused on aliphatic or cyclic alkenes (such as hexenes and cyclooctene) [7-9] and attempts to epoxidise an aromatic alkene (such as styrene) with hydrogen peroxide by employing catalysts $\left[\mathrm{Mo}^{\mathrm{V}}(\mathrm{O})(\mathrm{tpp})(\mathrm{X})\right](\mathrm{tpp}=$ meso-tetraphenylporphyrinato dianion, $\mathrm{X}=\mathrm{Cl}, \mathrm{OH}$, OMe, OAc, SCN) have failed [8].

Herein we report on the synthesis and structural characterisation of $\left[\mathrm{Mo}^{\mathrm{V}} \mathrm{O}\left(\mathrm{P}^{*}\right)(\mathrm{OMe})\right](1)$ bearing a chiral, $D_{4}$-symmetric $\mathrm{P}^{*}$ ligand $\left(\mathrm{H}_{2} \mathrm{P}^{*}=5,10,15,20\right.$-tetrakis $\{(1 S, 4 R, 5 R, 8 S)-1,2,3,4,5,6,7,8$-octahydro- $1,4: 5,8$ dimethanoanthracene-9-yl porphyrin), along with the catalytic behaviour of $\mathbf{1}$ toward the epoxidation of aromatic alkenes with tert-butyl hydroperoxide (TBHP), which represents the first molybdenum porphyrin-catalysed asymmetric epoxidation of alkenes. Our findings in this work highlight that chiral peroxo or alkylperoxo complexes of metalloporphyrins, which have not been studied before, are potentially useful for asymmetric alkene epoxidation. 


\section{Experimental}

\subsection{General procedure}

$\mathrm{Mo}(\mathrm{CO})_{6} \quad(98 \%), \quad$ 1,2,4-trichlorobenzene $(99+\%)$, and $\mathrm{H}_{2} \mathrm{O}_{2}$ (50 wt.\% in water) were purchased from Aldrich and were used as received. Styrene $(99+\%$, Aldrich) was purified by vacuum distillation, and 1,2dihydronaphthalene $(99+\%$, Aldrich $)$ by passing through a dry column of activated alumina. The chiral porphyrin $\mathrm{H}_{2} \mathrm{P}^{*}$ was synthesised according to the procedure of Halterman and co-workers [10]. cis- $\beta$-Methylstyrene was prepared by the general method of preparing cis-alkenes [11]. TBHP solution in 1,2dichloroethane $\left(4.1 \mathrm{M}\right.$, determined by ${ }^{1} \mathrm{H}-\mathrm{NMR}$ on a Bruker DPX-300 FT-NMR spectrometer) was obtained from an aqueous TBHP solution (70\%, Aldrich) by following the procedure described by Sharpless and Verhoeven [12]. IR spectrum was recorded on a Nicolet 20 FXC FT-IR spectrometer ( $\mathrm{KBr}$ pellet), UV-visible spectrum on a HP 8453 diode array spectrophotometer, ESR spectrum on a Bruker EMX100 ESR spectrometer. GC measurements were performed on a HP 5890 Series II system equipped with a HP 5890A flame ionisation detector and a HP 3395 integrator.

\subsection{Preparation of $\left[\mathrm{Mo}^{\mathrm{V}} \mathrm{O}\left(\mathrm{P}^{*}\right)(\mathrm{OMe})\right](\mathbf{1})$}

To a suspension of $\mathrm{H}_{2} \mathrm{P}^{*}(200 \mathrm{mg})$ in 1,2,4trichlorobenzene $\left(\mathrm{C}_{6} \mathrm{H}_{3} \mathrm{Cl}_{3}, 120 \mathrm{ml}\right)$ was added $\mathrm{Mo}(\mathrm{CO})_{6}(3.2 \mathrm{~g})$ under Ar. The mixture was stirred at $100{ }^{\circ} \mathrm{C}$ for $2 \mathrm{~h}$ and then refluxed for $48 \mathrm{~h}$. After removal of the solvent by distillation in vacuo, the residue was column-chromatographed on alumina. The first band containing unreacted $\mathrm{H}_{2} \mathrm{P}^{*}$ was removed with dichloromethane. The desired product was eluted with $\mathrm{CH}_{2} \mathrm{Cl}_{2}-\mathrm{MeOH}(1: 1 \mathrm{v} / \mathrm{v})$. Yield of 1: $\sim 80 \%$. IR (KBr): $909 \mathrm{~cm}^{-1}\left(v_{\mathrm{Mo}=\mathrm{O}}\right)$. ESR $\left(\mathrm{CHCl}_{3}, 298 \mathrm{~K}\right): \mathrm{g}=1.970$. Anal. Found: $\mathrm{C}, 75.67 ; \mathrm{H}, 6.22 ; \mathrm{N}, 3.41$. Calc. for $\mathrm{C}_{85} \mathrm{H}_{79} \mathrm{~N}_{4} \mathrm{MoO}_{2} \cdot 1.5 \mathrm{MeOH} \cdot 0.5 \mathrm{C}_{6} \mathrm{H}_{3} \mathrm{Cl}_{3}: \mathrm{C}, 75.53 ; \mathrm{H}$, $6.13 ; \mathrm{N}, 3.94 \%$.

\subsection{Epoxidation of aromatic alkenes catalysed by $\left[\mathrm{Mo}^{\mathrm{V}} \mathrm{O}\left(\mathrm{P}^{*}\right)(\mathrm{OMe})\right](\mathbf{1})$}

To a mixture of alkene $(1 \mathrm{mmol})$ and complex $1(0.01$ $\mathrm{mmol})$ in benzene $(2 \mathrm{ml})$ was added TBHP $(1.1 \mathrm{mmol})$. The solution was stirred at room temperature and aliquots were analysed by GC with G-TA chiral column.

\section{4. $X$-ray structure determination}

A single crystal $(\mathbf{1} \cdot 1.5 \mathrm{MeOH})$ of the dimensions $0.40 \times 0.35 \times 0.25 \mathrm{~mm}$, obtained from slow evaporation of a solution of 1 in $\mathrm{CH}_{2} \mathrm{Cl}_{2}-\mathrm{MeOH}$, was used for data collection on a Siemens SMART diffractometer (Mo$\mathrm{K}_{\alpha}$ radiation, $\lambda=0.71073 \AA$ ) at $295(2) \mathrm{K}$. The $\theta$ range for the data collection is $0.87-25.00^{\circ}$ and the limiting indices are $-49 \leq h \leq 49,-20 \leq k \leq 19$, and $-29 \leq$ $l \leq 29$. The structure was determined by employing SHELXTL programme and refined by full-matrix-block least-squares on $F^{2}$.

\section{Results and discussion}

\subsection{Synthesis and characterisation of complex 1}

Treatment of $\mathrm{Mo}(\mathrm{CO})_{6}$ with the chiral, sterically demanding porphyrin ligand $\mathrm{H}_{2} \mathrm{P}^{*}$ in refluxing 1,2 ,4trichlorobenzene under an inert atmosphere for $\sim 48 \mathrm{~h}$ followed by treating the reaction product with methanol led to isolation of the chiral molybdenum porphyrin complex 1 in $\sim 80 \%$ yield. This is similar to the literature method of preparing non-chiral oxoalkoxomolybdenum $(\mathrm{V})$ complexes with simple porphyrins (such as tpp) [13], except for the use of high-boiling 1,2,4-trichlorobenzene instead of decalin-octane as the reaction solvent and the requirement of a longer reaction time. Probably, the sterically demanding nature of the $\mathrm{H}_{2} \mathrm{P}^{*}$ ligand renders the insertion of molybdenum into this macrocycle more difficult. Note that when the reaction was carried out on a small scale, such as a tenth of the scale described in the Section 2, the main metalloporphyrin product isolated was an oxomolybdenum(IV) complex $\left[\mathrm{Mo}^{\mathrm{IV}} \mathrm{O}\left(\mathrm{P}^{*}\right)\right]$ rather than $\mathbf{1}$, as revealed by $U V$-visible spectroscopy and mass spectrometry.

Complex 1 exhibits an ESR signal with $g=1.970$ in chloroform at room temperature, consistent with the +5 oxidation state of its molybdenum centre. The IR spectrum of 1 shows $v_{\mathrm{Mo}=\mathrm{O}}$ at $909 \mathrm{~cm}^{-1}$. Both spectral features are similar to those reported for $\left[\mathrm{Mo}^{\mathrm{v}}(\mathrm{O})(\mathrm{tpp})\right.$ $(\mathrm{OMe})]\left(g=1.9687, v_{\mathrm{Mo}=\mathrm{O}}=905 \mathrm{~cm}^{-1}\right)$ [13].

$\mathrm{X}$-ray structure determination on $1 \cdot 1.5 \mathrm{MeOH}$ (see Table 1) reveals that the crystal unit cell contains two independent molecules of $\mathbf{1}$ with similar metrical parameters. The ORTEP drawing of one of the two molecules is depicted in Fig. 1. Selected bond lengths and angles of the molecule are listed in Table 2.

As is evident from Fig. 1 and Table 2, complex 1 has a distorted octahedral molybdenum centre. The mean $\mathrm{Mo}=\mathrm{O}$ bond length of $1(1.697(8) \AA)$ falls in the range of 1.673(3)-1.714(3) $\AA$ reported for those of $\left[\mathrm{Mo}^{\mathrm{v}} \mathrm{O}(\mathrm{tpp})(\mathrm{X})\right] \quad(\mathrm{X}=\mathrm{Cl}[14], \quad \mathrm{F}$ or $\mathrm{SCN}$ [15] but is appreciably smaller than that of $\left[\mathrm{Mo}^{\mathrm{v}} \mathrm{O}\right.$ (dptbtmp)(OMe)] (1.80(1) $\AA$, dptbtmp = 5,15-diphenyl2,8,12,18-tatra- $n$-butyl-3,7,13,17-tetramethylporphyrinato dianion) [16]. The mean Mo-OMe bond of $1.964(8) \AA$ in $\mathbf{1}$ is longer than that in 
Table 1

Crystal data and structure refinement for complex $\mathbf{1}$

\begin{tabular}{|c|c|}
\hline Formula & $\mathrm{C}_{85} \mathrm{H}_{79} \mathrm{~N}_{4} \mathrm{O}_{2} \mathrm{Mo} \cdot 1.5 \mathrm{CH}_{3} \mathrm{OH}$ \\
\hline Formula weight & 1332.53 \\
\hline Crystal system & Monoclinic \\
\hline Space group & $C 2 / c$ \\
\hline$a(\AA)$ & $41.3605(2)$ \\
\hline$b(\AA)$ & $17.1725(2)$ \\
\hline$c(\AA)$ & $24.8731(2)$ \\
\hline$\alpha\left({ }^{\circ}\right)$ & 90 \\
\hline$\beta\left({ }^{\circ}\right)$ & $109.281(1)$ \\
\hline$\gamma\left({ }^{\circ}\right)$ & 90 \\
\hline$V\left(\AA^{3}\right)$ & $16675.5(2)$ \\
\hline$Z$ & 8 \\
\hline$D_{\text {calc }}\left(\mathrm{g} \mathrm{cm}^{-3}\right)$ & 1.062 \\
\hline$F(000)$ & 5616 \\
\hline$T(\mathrm{~K})$ & $295(2)$ \\
\hline$\mu\left(\mathrm{Mo}-\mathrm{K}_{\alpha}\right)\left(\mathrm{cm}^{-1}\right)$ & 2.03 \\
\hline Reflections collected & 48551 \\
\hline No. of unique reflections & 27383 \\
\hline No. of parameters & 1610 \\
\hline$R_{1}$ & 0.1100 \\
\hline$w R_{2}$ & 0.2514 \\
\hline Goodness-of-fit & 1.145 \\
\hline Absolute structure parameter & $0.06(6)$ \\
\hline $\begin{array}{l}\text { Largest difference peak and hole } \\
\left(\mathrm{e} \AA^{-3}\right)\end{array}$ & 1.015 and -0.548 \\
\hline
\end{tabular}

$\left.\left[\mathrm{Mo}^{\mathrm{V}} \mathrm{O}(\mathrm{dptbtmp})(\mathrm{OMe})\right](1.89(1) \AA)^{\circ}\right)[16]$. The chiral porphyrin ligand $\mathrm{P}^{*}$ in $\mathbf{1}$ adopts a conformation similar to those in the structurally characterised ruthenium complexes with the $\mathrm{P}^{*}$ ligand such as $\left[\mathrm{Ru}^{\mathrm{VI}}\left(\mathrm{P}^{*}\right)(\mathrm{O})_{2}\right]$ [2b].
Table 2

Selected bond lengths $(\AA)$ and angles $\left(^{\circ}\right)$ for complex 1

\begin{tabular}{lclc}
\hline $\begin{array}{l}\text { Bond lengths } \\
\text { Mo-O(1) }\end{array}$ & $1.682(8)$ & $\mathrm{Mo}-\mathrm{O}(2)$ & $1.983(8)$ \\
$\mathrm{Mo}-\mathrm{N}(1)$ & $2.039(8)$ & $\mathrm{Mo}-\mathrm{N}(2)$ & $2.108(9)$ \\
$\mathrm{Mo}-\mathrm{N}(3)$ & $2.101(9)$ & $\mathrm{Mo}-\mathrm{N}(4)$ & $2.049(9)$ \\
$\mathrm{C}(85)-\mathrm{O}(2)$ & $1.32(2)$ & & \\
Bond angles & & & \\
$\mathrm{O}(1)-\mathrm{Mo}-\mathrm{O}(2)$ & $168.8(4)$ & $\mathrm{Mo}-\mathrm{O}(2)-\mathrm{C}(85)$ & $132(1)$ \\
$\mathrm{O}(1)-\mathrm{Mo}-\mathrm{N}(1)$ & $97.2(4)$ & $\mathrm{O}(1)-\mathrm{Mo}-\mathrm{N}(2)$ & $87.3(4)$ \\
$\mathrm{O}(1)-\mathrm{Mo}-\mathrm{N}(3)$ & $89.1(4)$ & $\mathrm{O}(1)-\mathrm{Mo}-\mathrm{N}(4)$ & $99.6(4)$ \\
$\mathrm{O}(2)-\mathrm{Mo}-\mathrm{N}(1)$ & $89.2(4)$ & $\mathrm{O}(2)-\mathrm{Mo}-\mathrm{N}(2)$ & $83.4(4)$ \\
$\mathrm{O}(2)-\mathrm{Mo}-\mathrm{N}(3)$ & $84.6(3)$ & $\mathrm{O}(2)-\mathrm{Mo}-\mathrm{N}(4)$ & $89.7(4)$ \\
$\mathrm{N}(1)-\mathrm{Mo}-\mathrm{N}(2)$ & $90.2(3)$ & $\mathrm{N}(2)-\mathrm{Mo}-\mathrm{N}(3)$ & $90.1(3)$ \\
$\mathrm{N}(3)-\mathrm{Mo}-\mathrm{N}(4)$ & $89.9(3)$ & $\mathrm{N}(1)-\mathrm{Mo}-\mathrm{N}(4)$ & $89.1(3)$ \\
\end{tabular}

\subsection{Asymmetric epoxidation of aromatic alkenes with TBHP catalysed by complex 1}

The catalytic behaviour of $\mathbf{1}$ toward asymmetric epoxidation of aromatic alkenes with TBHP was examined first with styrene (2a) as a substrate. When a mixture of styrene and TBHP in benzene in the presence of $1 \mathrm{~mol} \%$ complex 1 was stirred at room temperature for $16 \mathrm{~h}$, styrene epoxide (3a) was formed in $16 \%$ ee with catalyst turnovers of 4 (entry 1 in Table 3); no $3 \boldsymbol{a}$ was detected if the same reaction was carried out in the absence of complex $\mathbf{1}$. We found that the predominant enantiomer of 3a adopts a $(R)$-configuration, which is different from the $(S)$-configuration observed in the $\mathrm{NaOCl}$ epoxidation of the same aromatic alkene catalysed by $\left[\mathrm{Mn}^{\mathrm{III}}\left(\mathrm{P}^{*}\right) \mathrm{Cl}\right][10 \mathrm{~b}]$.

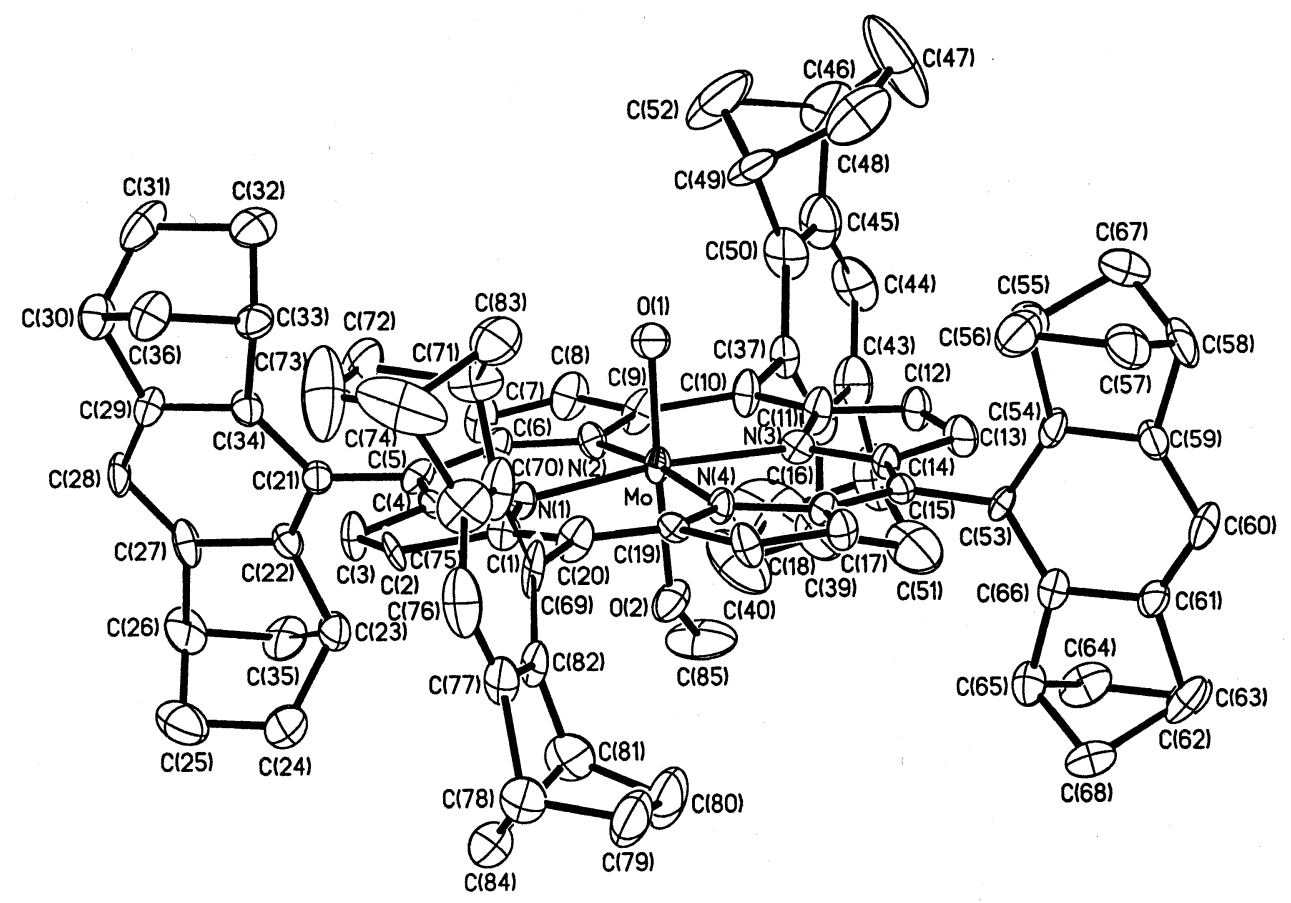

Fig. 1. ORTEP drawing of one of the two independent molecules of $\mathbf{1}$ in the crystal structure of $1 \cdot 1.5 \mathrm{MeOH}$ with thermal ellipsoids drawn at the $30 \%$ probability level (hydrogen atoms are not shown). 
Extension of the complex 1-TBHP system to other aromatic alkenes, including cis- $\beta$-methylstyrene (cis-2b) and 1,2-dihydronaphthalene (4), led to higher catalyst turnovers or enantioselectivity (entries $2-6$ in Table 3 ). The epoxidation of cis-2b afforded a mixture of cisand trans-3b with the cis epoxide formed in much higher ee (up to $29 \%$, entries $2-5$ ). Of interest is the large dependence of the cis:trans ratio of $\mathbf{3 b}$ on the reaction time. For example, the cis:trans ratio decreased from 36:64 to 9:91 as the reaction time increased from 3 to $30 \mathrm{~h}$. Such a time dependence of cis:trans ratio is unlikely to arise from an isomerisation of cis- to trans-3b catalysed by complex $\mathbf{1}$, since no trans-3b was observed after a mixture of cis-3b and complex 1 had been stirred for $24 \mathrm{~h}$ under the same conditions as those employed for the catalytic reaction.

The mechanism of the foregoing complex 1-catalysed epoxidations is not yet clear. Since the closely related TBHP epoxidations of alkenes catalysed by molybde-

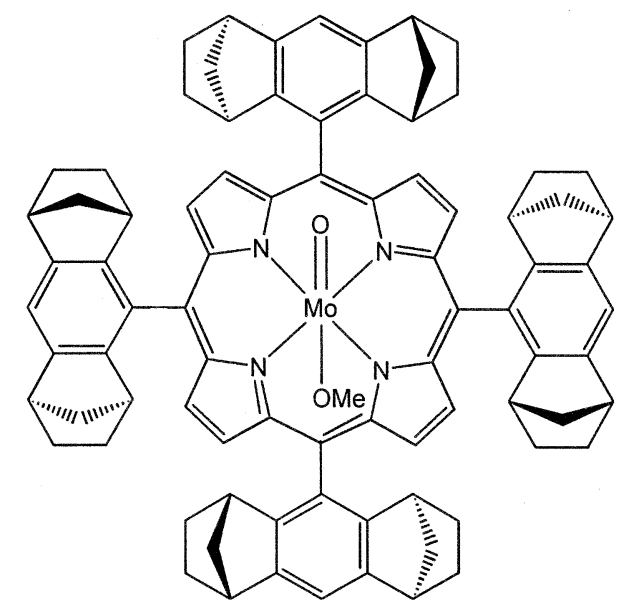

1 num porphyrins $\left[\mathrm{Mo}^{\mathrm{V}} \mathrm{O}(\mathrm{tpp}) \mathrm{X}\right](\mathrm{X}=\mathrm{Cl}, \mathrm{OMe})$ and cis$\left[\mathrm{Mo}^{\mathrm{VI}}(\mathrm{tpp})(\mathrm{O})_{2}\right]$ most probably proceed via a $\mathrm{Mo}-\mathrm{OOBu}^{t}$ (rather than $\mathrm{Mo}=\mathrm{O}$ ) active intermediate [7], we propose that a similar active intermediate may be involved in the complex 1-TBHP system. However, our attempts to isolate or characterise any $\mathrm{Mo}-\mathrm{OOBu}{ }^{t}$ species from the reaction of $\mathbf{1}$ with TBHP were unsuccessful.

Inasmuch as molybdenum porphyrins can also catalyse epoxidation of alkenes with $\mathrm{H}_{2} \mathrm{O}_{2}$ [8,9], we then examined the reaction between complex 1 and $\mathrm{H}_{2} \mathrm{O}_{2}$, attempting to isolate the porphyrin product in the reaction and examine its reactivity toward stoichiometric epoxidation of alkenes. Treatment of 1 with excess $\mathrm{H}_{2} \mathrm{O}_{2}$ in dichloromethane-methanol $(8: 2 \mathrm{v} / \mathrm{v})$ resulted in a slow colour change of the mixture from green to red brown. Removal of unreacted $\mathrm{H}_{2} \mathrm{O}_{2}$ and chromatography on a short basic alumina column followed by crystallisation from pentane afforded a chiral molybdenum porphyrin (6) as a red-brown solid in $\sim 40 \%$ yield. The UV-visible spectrum of 6 in dichloromethane shows bands at 422 (Soret), 518, and $647 \mathrm{~nm}$, which is different from those of trans-diperoxo- [17] or cis-dioxomolybdenum(VI) [18] porphyrins. In the positive-ion FAB mass spectrum of $\mathbf{6}$, there are cluster peaks at $m / z 1253,1269$ and 1285 ascribable to $\left[\mathrm{MoO}\left(\mathrm{P}^{*}\right)\right]^{+},\left[\mathrm{Mo}\left(\mathrm{P}^{*}\right)\left(\mathrm{O}_{2}\right)\right]^{+}$, and $\left[\mathrm{MoO}\left(\mathrm{P}^{*}\right)\left(\mathrm{O}_{2}\right)\right]^{+}$, respectively. We speculate that complex $\mathbf{6}$ belongs to a $\left[\mathrm{MoO}\left(\mathrm{P}^{*}\right)\left(\mathrm{O}_{2}\right)\right]$ species, and efforts to obtain single crystals of $\mathbf{6}$ are under way.

Interestingly, complex $\mathbf{6}$ is reactive toward aromatic alkenes such as $c i s-\mathbf{2 b}$. When a solution of $\mathbf{6}$ and $c i s-\mathbf{2 b}$ in 1,2-dichloroethane was stirred at room temperature for $23 \mathrm{~h}$, a mixture of cis-and trans $\mathbf{- 3 b}$ was formed in a 58:42 ratio, with 31 and $11 \%$ ee obtained for the cis and trans epoxide, respectively.

Table 3

Epoxidation of aromatic alkenes with TBHP catalysed by complex $\mathbf{1}$

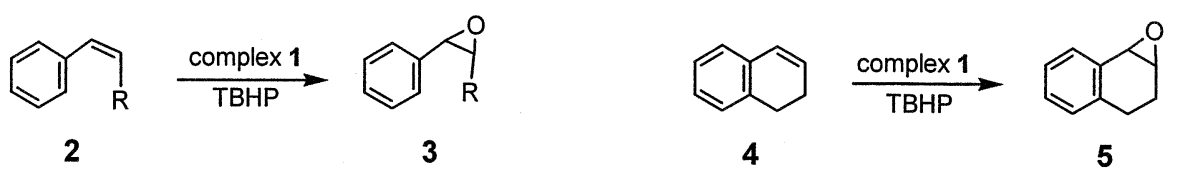

\begin{tabular}{|c|c|c|c|c|c|c|c|}
\hline Entry & $\mathrm{R}$ & Alkene & Product & Time (h) & $\mathrm{TON}^{\mathrm{a}}$ & cis:trans & ee $(\%)^{b}$ \\
\hline 1 & $\mathrm{H}$ & $\mathbf{2 a}$ & $3 \mathbf{a}$ & 16 & 4 & & 16 \\
\hline 2 & $\mathrm{Me}$ & cis $\mathbf{- 2 b}$ & cis -+ trans $\mathbf{- 3 b}$ & 3 & 3 & $36: 64$ & $29^{\mathrm{c}}$ \\
\hline 3 & $\mathrm{Me}$ & & & 4 & 5 & $30: 70$ & $28^{\mathrm{c}}$ \\
\hline 4 & $\mathrm{Me}$ & & & 15 & 11 & $17: 83$ & $26^{c}$ \\
\hline 5 & $\mathrm{Me}$ & & & 30 & 27 & 9:91 & $24^{\mathrm{c}}$ \\
\hline 6 & $\left(\mathrm{CH}_{2}\right)_{2}$ & 4 & 5 & 16 & 5 & & 10 \\
\hline
\end{tabular}

\footnotetext{
a (Moles of epoxides)/(moles of complex 1).

b Absolute configuration: $(R)(\mathbf{3 a}),(1 R, 2 S)($ cis-3b, 5), $(1 R, 2 R)$ (trans-3b).

${ }^{\mathrm{c}}$ Ee of cis-3b. The ee of trans-3b is $\sim 1 \%$ in all cases.
} 


\section{Supplementary material}

Crystallographic data for the structural analysis have been deposited with the Cambridge Crystallographic Data Centre, CCDC no. 161122. Copies of this information may be obtained free of charge from the Director, CCDC, 12 Union Road, Cambridge CB2 1EZ, UK (Fax: + 44-1223-336033; e-mail: deposit@ccdc.cam. ac.uk or www: http://www.ccdc.cam.ac.uk).

\section{Acknowledgements}

This work was supported by The University of Hong Kong, the Hong Kong Research Grants Council (HKU 7092/98P and PolyU 1/97C), and the Hong Kong University Foundation.

\section{References}

[1] J.P. Collman, X.M. Zhang, V.J. Lee, E.S. Uffelman, J.I. Brauman, Science 261 (1993) 1404 and references therein.

[2] (a) A. Berkessel, M. Frauenkron, J. Chem. Soc. Perkin Trans. 1 (1997) 2265

(b) T.-S. Lai, R. Zhang, K.-K. Cheung, H.-L. Kwong, C.-M. Che, Chem. Commun. (1998) 1583;

(c) Z. Gross, S. Ini, Inorg. Chem. 38 (1999) 1446.
[3] B. Meunier, Chem. Rev. 92 (1992) 1411.

[4] See for example: (a) J. Sundermeyer, Angew. Chem. Int. Ed. Engl. 32 (1993) 1144. (b) E.N. Jacobsen, in: E.W. Abel, F.G.A. Stone, G. Wilkinson (Eds.), Comprehensive Organometallic Chemistry II, vol. 12, Pergamon, Oxford, 1995, chapter 11.1.

[5] T.S. Srivastava, E.B. Fleischer, J. Am. Chem. Soc. 92 (1970) 5518.

[6] (a) Y. Matsuda, Y. Murakami, Coord. Chem. Rev. 92 (1988) 157 ;

(b) H. Brand, J. Arnold, Coord. Chem. Rev. 140 (1995) 137.

[7] H.J. Ledon, P. Durbut, F. Varescon, J. Am. Chem. Soc. 103 (1981) 3601

[8] G. Legemaat, W. Drenth, M. Schmidt, G. Prescher, G. Goor, J. Mol. Catal. 62 (1990) 119.

[9] P. Hoffmann, B. Meunier, New J. Chem. 16 (1992) 559.

[10] (a) R.L. Halterman, S.-T. Jan, J. Org. Chem. 56 (1991) 5253; (b) R.L. Halterman, S.-T. Jan, H.L. Nimmons, D.J. Standlee, M.A. Khan, Tetrahedron 53 (1997) 11257.

[11] H. Lindlar, R. Dubuis, Org. Synth. Collect. 5 (1973) 880.

[12] K.B. Sharpless, T.R. Verhoeven, Aldrichim. Acta 12 (1979) 63.

[13] H.J. Ledon, M.C. Bonnet, Y. Brigandat, F. Varescon, Inorg. Chem. 19 (1980) 3488.

[14] H. Ledon, B. Mentzen, Inorg. Chim. Acta 31 (1978) L393.

[15] T. Imamura, A. Furusaki, Bull. Chem. Soc. Jpn 63 (1990) 2726.

[16] M. van Dijk, Y. Morita, S. Petrovic, G.M. Sanders, H.C. van der Plas, C.H. Stam, Y. Wang, J. Heterocyclic Chem. 29 (1992) 81.

[17] B. Chevrier, Th. Diebold, R. Weiss, Inorg. Chim. Acta 19 (1976) L57.

[18] T. Malinski, P.M. Hanley, K.M. Kadish, Inorg. Chem. 25 (1986) 3229. 